\title{
THE DISTRIBUTION OF BODY FLUIDS OF DOGS IN TRAUMATIC SHOCK ${ }^{1}$
}

\author{
By RENATO A. RICCA, K. FINK, L. T. STEADMAN, AND STAFFORD L. WARREN \\ (From the Department of Radiology of the University of Rochester School of Medicine and Dentistry, \\ Rochester, $N$. Y.)
}

(Received for publication June 5, 1944)

\section{INTRODUCTION}

For some time, there have been contradictory reports in the literature as to the distribution of body fluids during shock and the extent of change in the protein balance between the blood and traumatized area in the case of traumatized shock. The present study deals with this problem' in the case of traumatic shock produced by the Blalock press in anesthetized dogs.

Very little actual experimental information as to what happens to tissue fluids during shock is available. One author (1) maintained that in traumatic shock the tissue fluids are increased due to escape of plasma from the capillary bed. Others (2) showed (from gross and microscopic observations) that early in traumatic shock the tissue fluids are not increased. Blalock (3) indicated that early in traumatic shock the tissue fluids are decreased. Two other investigators (4) claim that their evidence indicates an increase in interstitial fluid and a decrease in intracellular fluid during traumatic shock. We have not conducted our experiments with a view to distinguishing between interstitial and intracellular water. Our results, in general, show that there is a decrease in tissue fluids and various degrees of hemoconcentration in dogs which succumbed to traumatic shock, and that most of the water loss can be accounted for in the fluid that has accumulated in the traumatized limb. These gains and losses or shifts in body fluids seem to bear no primary relation to the death of the animal from acute shock resulting from this type of trauma.

1 The work described in this paper was done under a contract, recommended by the Committee on Medical Research, between the Office of Scientific Research and Development and the University of Rochester School of Medicine and Dentistry. Part of the work was also assisted by grants in aid from the Rockefeller Foundation and the Fluid Research Fund of the University of Rochester.

\section{METHODS}

The standardized method of producing shock as a result of a crushing injury has been previously described (5). Briefly, it consists of the confinement of one hind extremity of a dog in a press for 5 hours. Following the removal of the press, the animals developed a fatal shock state. For consistent and reproducible results, the over-all pressure exerted on the soft tissues of the limb and the environmental temperatures must be controlled (5). In all the experiments, sodium pentobarbital anesthesia was used as previously described. A typical experiment has been described (5), and, in addition, blood samples were taken for electrolyte analyses, tissue samples were taken at autopsy for determination of water and electrolyte content, and leg fluid was obtained from the traumatized limb for chemical study.

Sections of tissue analyzed for water content were removed at autopsy done immediately after death of the animal. The tissue sections were weighed in suitable containers and then dried in an oven. They were then re-weighed after drying at $100^{\circ} \mathrm{C}$. for 48 hours, and the water content found by subtracting the latter value from the first. The dogs from which tissues were taken for analyses of water content were not given water once the press was applied on the limb.

Serum and plasma protein concentrations were'done by the micro-Kjeldahl method. Albumin-globulin ratios were determined by precipitating the globulin with 22 per cent sodium sulfate (6), and then determining the albumin nitrogen in the filtrate by the micro-Kjeldahl method. NPN was determined by the method of Koch and McMeekin (7).

Hematocrits were determined in calibrated centrifuge tubes, using 12 to $14 \mathrm{ml}$. of blood. Potassium oxalate, in a concentration of $2 \mathrm{mgm}$. per $\mathrm{ml}$. of blood, was employed as anticoagulant.

To compare the weights of the traumatized extremity and the normal hind extremity, at autopsy the hind quarters were bisected according to the method described by Blalock (3).

Circumferences of both the traumatized extremity and normal hind extremity were measured 3 hours after removal of the press and at autopsy at 3 different positions.

Dogs succumbing within 24 hours after removal of the press were counted as deaths due to acute shock. Those surviving after 24 hours were counted as survivals. The survival groups discussed in this paper include only dogs done at low room temperatures (5). 
Losses in plasma volume were computed by hematocrit changes. We are well aware of the inaccuracies of this method, but these will not influence our conclusions since we shall consider only large changes in the neighborhood of 100 per cent.

The concentrations of sodium, potassium, magnesium, calcium, and total phosphorus were determined by spectrochemical methods $(8,9)$. Fresh tissue samples of about one gram, upon which the fat content had been roughly determined, were used in all cases. They were digested in nitric acid preparation for the analyses.

\section{RESULTS}

Shortly after removing the press, the traumatized extremity commenced to swell. Usually within 1 hour the thigh was swollen to the extent that the depressions left by the press were no longer visible. However, in some cases the extremity swelled so little that at death the depressions were still visible. In general, the amount of leg swelling gave no indication as to whether or not the animal would survive. There were many cases in which the swelling 3 hours after removal of the press was very great, and the dogs survived. Also, there were many cases in which the swelling was slight, and the dogs succumbed. Table I summarizes the increase in

\section{TABLE I}

Increase in leg circumference 3 hours after press remooal

Two thousand pounds pressure on one hind limb for 5 hours. Veterinary Nembutal anesthesia. There is no significant difference in the amount of leg swelling between deaths and survivals. The survival group represents dogs done at low room temperatures.

\begin{tabular}{c|c|c|c|c}
\hline \hline \multirow{2}{*}{$\begin{array}{c}\text { No. of } \\
\text { dogs }\end{array}$} & Results & \multicolumn{3}{|c}{$\begin{array}{c}\text { Averages of increase in } \\
\text { circumferences of traumatized legs }\end{array}$} \\
\cline { 3 - 4 } & & Groin & $\begin{array}{c}2 \text { inches } \\
\text { above knee }\end{array}$ & $\begin{array}{c}2 \text { inches } \\
\text { below knee }\end{array}$ \\
\hline & & \multicolumn{4}{|c|}{ per cent } \\
31 & & 19 & 18 & 21 \\
25 & Deaths & 19 & 21 & 14 \\
\hline
\end{tabular}

leg circumferences 3 hours after press removal. It is to be noted that, on the average, the amount of swelling was the same in the dogs which survived as in those which succumbed.

Figure 1 is a spot graph of percentage increase in hematocrit at exitus over the control value plotted against gain in leg weight expressed as gain in percentage of body weight. In general, the hematocrit increase at exitus gives no indica-

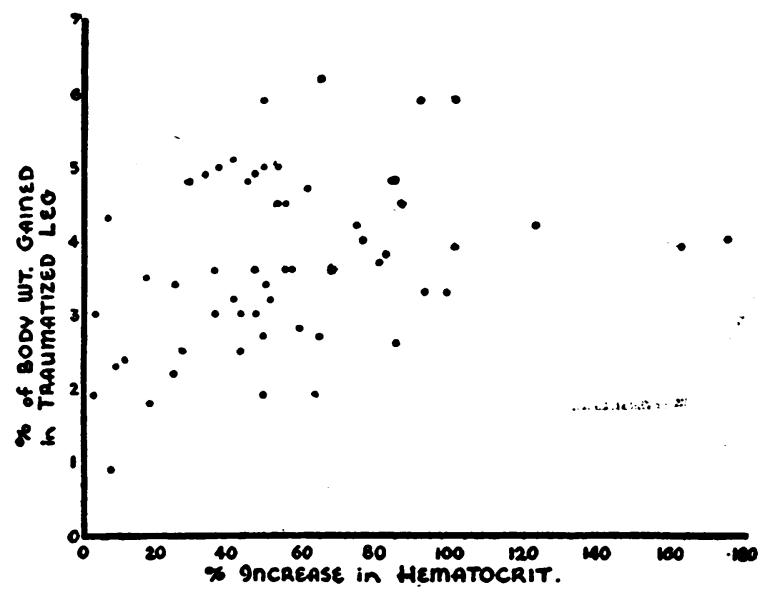

Fig. 1. There is No Relationship Between Increase in HeMatocrit at Exitus aNd InCREase in Weight of the Traumatized Extremity

tion as to the volume of fluid accumulated in the traumatized extremity.

The fluid which extravasated into the traumatized area was collected shortly after the animal either succumbed or was sacrificed, and was easily squeezed out from the interfascial planes. It was light pink in color and clotted very rapidly unless about $12 \mathrm{mgm}$. of potassium oxalate per ml. of fluid were used as anticoagulant. The results of the various chemical determinations on the leg fluid are tabulated in Table II. As can be seen from the Table, the protein concentration of the leg fluid is roughly about the same as the serum protein concentration.

The chemical albumin-globulin ratios of the leg fluid however were increased in every case as compared to the ratios of the serum at exitus, this being affected by either an increase in albumin or a decrease in globulin concentrations, or both. In a series of 48 dogs, the chemical A-G ratios of the exitus serum samples were not altered significantly as compared to the control samples. The albumin/globulin ratios as determined, however, did not agree with electrophoretic measurements.

The non-protein nitrogen concentration was greater in the leg fluid than in the exitus blood sample in all but one case. These values are also included in Table II.

In a series of 67 dogs, the average gain in weight of the traumatized extremity was 769 grams with a range from 110 grams to 2050 
TABLE II

Determinations on dogs from which leg fluid was collected

Two thousand pounds over-all pressure on one hind limb for 5 hours Veterinary Nembutal anesthesia.

\begin{tabular}{|c|c|c|c|c|c|c|c|c|c|c|c|c|c|c|c|c|c|}
\hline \multirow[b]{2}{*}{ 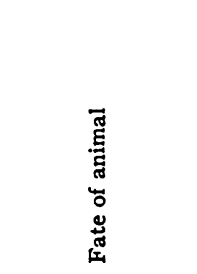 } & \multirow[b]{2}{*}{ 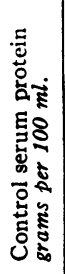 } & \multicolumn{5}{|c|}{ Exitus serum values } & \multicolumn{5}{|c|}{ Leg fluid values } & \multicolumn{2}{|c|}{ Hematocrit } & \multirow[b]{2}{*}{ 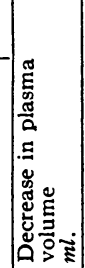 } & \multirow[b]{2}{*}{ 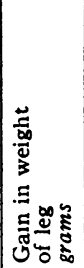 } & \multirow[b]{2}{*}{ 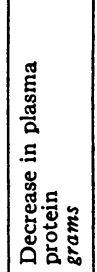 } & \multirow[b]{2}{*}{ 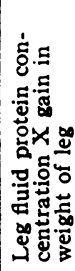 } \\
\hline & & 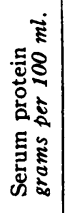 & 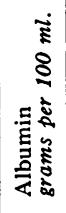 & 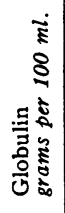 & 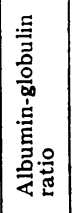 & 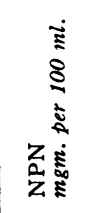 & 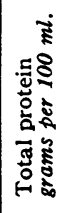 & 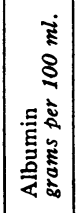 & 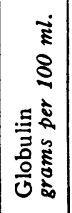 & 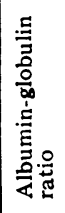 & 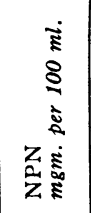 & 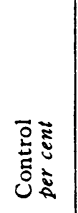 & 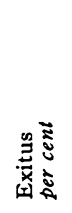 & & & & \\
\hline Sacr., 15 hrs. & $5.3^{*}$ & $5.1^{*}$ & 3.4 & 1.4 & 2.4 & $47.6 \ddagger$ & 3.7 & 2.7 & 0.96 & 2.8 & & 53.0 & 61.3 & 116 & & 7.2 & \\
\hline & & 6.3 & 38 & 25 & 15 & $\begin{array}{l}42.2 \ddagger \\
76.3\end{array}$ & $\begin{array}{l}3.8 \\
6.4\end{array}$ & $\begin{array}{l}2.7 \\
4.5\end{array}$ & $\begin{array}{l}1.1 \\
1.9\end{array}$ & $\begin{array}{l}2.5 \\
2.4\end{array}$ & $\begin{array}{r}41.5 \\
142.0\end{array}$ & & & $\begin{array}{l}181 \\
189\end{array}$ & & & \\
\hline$\vec{S}$ & 6.3 & 6.4 & 3.7 & 2.7 & 1.4 & 28.5 & 4.1 & 2.7 & 1.4 & 1.9 & $\begin{array}{r}142.0 \\
46.9\end{array}$ & $\begin{array}{l}40.5 \\
34.1\end{array}$ & & 335 & 470 & 20.6 & 19.3 \\
\hline & 6. & 6.4 & 4.1 & 2.3 & 1.8 & 70.0 & 5.8 & 4.1 & 1.7 & 2.4 & 89.8 & & 70 & 587 & 1310 & 36.3 & 76.0 \\
\hline & & $5.1^{*}$ & 2.4 & 2.3 & 1.0 & & 5.3 & 4.2 & 1.1 & 3.8 & 71.0 & & & 403 & & 22.9 & \\
\hline & & & & 2.6 & & 48.0 & 5.6 & 3.6 & 2.0 & & & & & & & 12.3 & \\
\hline $\mathrm{Di}$ & & 6.7 & 3.8 & 2.3 & 1.7 & $102.0 \ddagger$ & 5.6 & 3.9 & 1.7 & 2.3 & & 45.2 & 64 & 403 & 1280 & 17.8 & 71.7 \\
\hline $7 \frac{1}{2} \mathrm{hrs}$. & & $6.6^{*}$ & 3.1 & 3.0 & 1.0 & $93.2 \ddagger$ & 6.1 & 3.9 & 2.3 & 1.8 & 138.0 & & 62 & & & & \\
\hline $6 \frac{1}{2} \mathrm{hrs}$ & & $6.2^{*}$ & 2.3 & 3.5 & 0.66 & $64.2 \ddagger$ & 6.3 & 3.3 & 3.0 & 1.1 & 86.4 & & & & & & \\
\hline & & $8.0^{*}$ & & & & & 6.2 & & 2.5 & & 100.1 & & & 441 & 870 & 13.0 & \\
\hline & & $7.3^{*}$ & & 1.9 & 2.6 & 92 & & 4 & 1.6 & 2.8 & & & & & & 18.5 & \\
\hline & 6.3 & 8.7 & 5.0 & 3.7 & 1.4 & 59.0 & 6.3 & 4.6 & 1.7 & 2.7 & 180.0 & 39.1 & 56.6 & 273 & 680 & 0.9 & 42.8 \\
\hline
\end{tabular}

grams. The average decrease in plasma volume, calculated from hematocrit changes, was $319 \mathrm{ml}$. with a range from $21 \mathrm{ml}$. to $617 \mathrm{ml}$. The accumulation of fluid in the traumatized extremity was greater than could be accounted for by the decrease in plasma volume in every animal but one.

In the experiments included in Table II, the decrease in plasma volume can be calculated from the change in hematocrit. From the volume of lost plasma, the amount of protein lost from the circulatory system may be computed. From the gain in weight of the traumatized extremity and the protein concentration in the leg fluid, the total amount of protein present in the leg fluid can be calculated. On comparing these two sets of values, included in the last two columns of Table II, it can be seen that there is much more protein in the leg fluid than can be accounted for by the loss of circulating plasma protein.

The determinations of water content of various tissues are included in Table III. The results show that there is a small loss of water from each of the non-traumatized tissues with the exception of the liver and testes which comprise a very small fraction of the total body volume.
The traumatized muscles show a gain in water content.

TABLE III

Determinations of water content of various tissues

The figures in the first column are averages of 3 normal dogs. Those in the second column are averages of 12 dogs which expired in shock.

\begin{tabular}{|c|c|c|c|}
\hline \multirow{2}{*}{ Tissue } & \multicolumn{3}{|c|}{ Water content } \\
\hline & Normal & $\underset{\text { shock }}{\text { Traumatic }}$ & Difference \\
\hline $\begin{array}{l}\text { Brain } \\
\text { Spleen } \\
\text { Liver } \\
\text { Pancreas } \\
\text { Kidney } \\
\text { Diaphragm } \\
\text { Lungs } \\
\text { Heart } \\
\text { Duodenum } \\
\text { Jejunum } \\
\text { Ileum } \\
\text { Skin } \\
\text { Testes } \\
\text { Chest muscle } \\
\text { Quadriceps femoris } \\
\text { Biceps femoris } \\
\text { Lateral aspect of thigh } \\
\text { Quadriceps femoris } \\
\text { Biceps femoris } \\
\text { Lateral aspect of thigh }\end{array}$ & $\begin{array}{l}81.6 \\
81.1 \\
74.9 \\
75.4 \\
83.7 \\
76.9 \\
81.1 \\
79.5 \\
76.8 \\
78.1 \\
78.5 \\
58.5 \\
84.9 \\
75.2 \\
75.4 \\
78.9 \\
79.1\end{array}$ & $\begin{array}{c}\text { per cent } \\
78.9 \\
78.8 \\
75.6 \\
73.3 \\
79.8 \\
75.0 \\
78.2 \\
79.3 \\
76.6 \\
77.8 \\
75.2 \\
50.6 \\
85.0 \\
72.6 \\
73.9 \ddagger \\
71.3 \ddagger \\
74.9 \ddagger \\
81.4^{*} \\
79.8^{*} \\
81.9^{*}\end{array}$ & $\begin{array}{l}-2.7 \\
-2.3 \\
+0.7 \\
-2.1 \\
-3.9 \\
-1.9 \\
-2.9 \\
-0.2 \\
-0.2 \\
-0.3 \\
-3.3 \\
-7.9 \\
+0.1 \\
-2.6 \\
-1.5 \\
-7.6 \\
-4.2 \\
+7.5 \\
+8.5 \\
+7.0\end{array}$ \\
\hline
\end{tabular}

† Samples taken from untraumatized leg.

* Samples taken from traumatized leg; increases are expressed relative to the untraumatized leg. 
The results of electrolyte studies are given in Table IV. The values given for serum, erythrocytes, and spinal fluid are the percentage changes obtained by comparison of the normal samples taken just before anesthesia was given and the samples during the shock state which were withdrawn 3 hours after the removal of the press.

TABLE IV

\section{Percentage changes in concentrations of electrolytes during traumatic shock}

The values shown are an average of the number of dogs used.

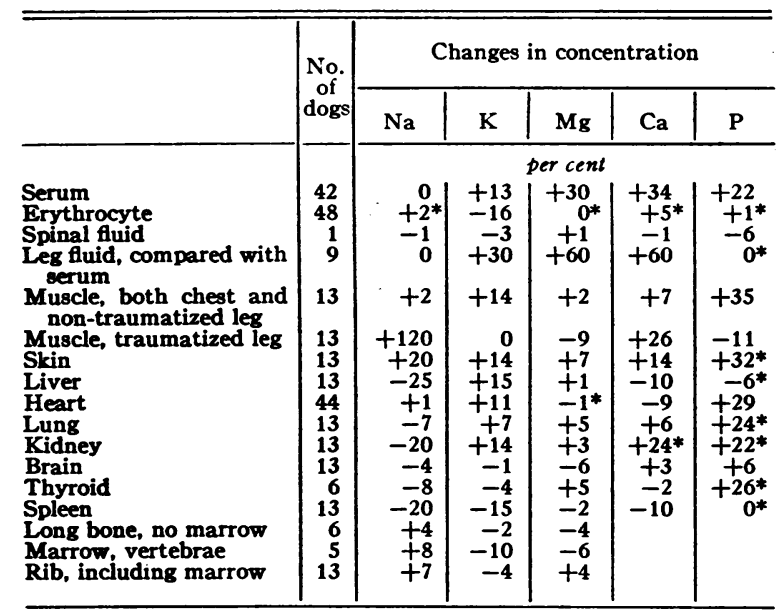

* Large individual variation.

The percentage changes given for leg fluid were calculated by comparison with normal serum levels. The figures shown in the Table for the remaining tissues are based on the electrolyte concentrations of the tissues taken from the shocked animals at autopsy. compared with the average concentrations obtained on tissues taken from six normal dogs which had no anesthesia.

Changes in electrolyte concentrations of less than 10 per cent for lung, bone, marrow, and rib, and changes less than 5 per cent for all the other tissues and fluids are probably not significant considering the standard errors of the method, the number of animals used, and individual variation.

The alterations in electrolyte concentration of the serum were quite consistent from animal to animal. The concentrations of potassium, magnesium, calcium, and phosphorus were all elevated. The hematocrit increased an average of $\mathbf{4 5}$ per cent over the same period of time, so loss of fluid from the serum may partially or completely account for the elevated concentration of these electrolytes. Simple loss of water alone from the circulating plasma, however, cannot be the answer, since the percentage increases were not the same, and the sodium concentration remained unaltered. A portion of the rise in serum magnesium is probably a result of the anesthesia. Eight control dogs given the standard amount of Nembutal were studied. The average changes in the concentration of serum electrolytes in these dogs were: sodium, +2 per cent; potassium, +6 per cent; magnesium, +14 per cent; calcium, 0 per cent; and phosphorus, +4 per cent. Serum values generally returned to normal within a few hours if the animal survived.

The only uniform change of electrolyte concentration observed in the erythrocytes was an average decrease of 16 per cent in the potassium level. There was a considerable scatter in the concentration of sodium, magnesium, calcium, and phosphorus in the red blood cells examined from 42 animals, but the averages were small. The erythrocyte loss in potassium may contribute to the serum rise in potassium, but no correlation was observed between the corresponding serum and red cell changes for magnesium, calcium, or phosphorus.

The spinal fluid from lumbar puncture was analyzed in one dog and no significant change was found in its electrolyte content.

The leg fluid extravasated in the traumatized leg had about the same sodium and phosphorus concentrations as normal serum, but the levels of potassium, magnesium, and calcium were elevated. Changes were also observed in the muscle itself, taken from the traumatized leg. In this injured tissue, the sodium concentration was more than doubled, possibly because of influx of plasma into the leg, the calcium level increased about 25 per cent, the potassium concentration remained unaltered, and the levels of magnesium and phosphorus fell about 10 per cent.

In Table IV, it can be seen that there are changes in electrolyte concentration in some of the other tissues examined. The trends, in the main, were fairly uniform from animal to animal, but considerable variation is indicated by an asterisk. 
The measurements on the muscles, including the heart, are the most extensive, and therefore the results are the most accurate. It is believed that the analyses do not indicate any significant electrolyte changes in the lung, brain, thyroid, bone, and bone marrow. A unified picture, or interpretation of all the results, has not been worked out.

Electrolyte measurements were also made, with the exception of erythrocytes, spinal fluid, and leg fluid, on 9 traumatic shock dogs which had ice applied to the crushed leg, as described in another paper of this series (5). The changes found are in almost complete agreement with the values given herewith for the experiments in which no ice was applied.

\section{DISCUSSION}

During the course of our experimental series, a crushing injury was produced in a total of over 300 dogs. An observation which impressed us greatly was that survival or death of the animal could not be predicted from the amount of leg swelling during the course of the experiment. Leg circumference measurements on a great number of dogs confirmed this impression.

There are two possible interpretations of these results. One is that there is some as yet unknown factor of paramount importance other than fluid loss in the syndrome of shock. The other is that the general condition and state of hydration of the animal may determine whether, with a given fluid loss, he may survive or succumb. The animals used in these experiments were in good condition. There was no correlation between either initial hematocrit or final hematocrit or change in hematocrit, and survival or death, or the survival time of the animals. The same holds true for serum protein concentration. In view of these negative findings, we do not believe that the above results can be explained on the basis of individual reaction merely to fluid loss.

The fluid which accumulated in the traumatized extremity was much greater in amount than could be accounted for by simple loss of plasma. The results of the determinations of tissue water content show a general fall in water content of most of the organs during shock, and a gain in water in the traumatized muscles.
These results on the water content of the tissues in traumatic shock are in agreement with those reported by others (10). It has been shown (5) that there is an increase in serum protein concentration during this particular type of shock. This increases the effective osmotic pressure of the blood and facilitates the transport of water from the rest of the tissues to the traumatized area.

There is a greater total amount of protein in the leg fluid than can be accounted for by loss of protein from the circulation alone. A greater proportion of this leg fluid protein is represented in the chemically determined albumin fraction as compared to the corresponding fraction of the serum protein. It is unlikely that this extra protein is mobilized to this extent from the body stores and deposited in the traumatized area within the relatively short period of these experiments ( $1 \frac{1}{2}$ to 15 hours). Other investigators (11) have shown that dogs replace only a very small fraction of the removed plasma proteins while in the acute shock state from hemorrhage. This high protein value, therefore, probably originates in the rupture of crushed muscle fibers with the liberation of cell proteins locally.

The greater concentration of non-protein nitrogen in the leg fluid as compared to that in the serum is probably also the result of enzymatic digestion of proteins liberated from ruptured cells. The elevated NPN, noted by many observers as well as ourselves, during traumatic shock, may be due to a large extent to absorption of products of protein break-down from the traumatized area. The possibility of these and other substances being toxic to the organism has been discussed (12), and is worthy of further study.

The variations in electrolyte levels found in these experiments are in fair agreement with the results noted by other workers $(4,13$ to 17$)$. There are, two exceptions, however. The 100 per cent or greater rise in serum potassium at about the time of exitus observed by two investigators (15) has not been encountered by us. But no attempt was made to verify this finding and probably blood samples were never taken at the right time to obtain the very high potassium level. The different way of crushing the tissue may also have some significance in this respect. 
One group of workers (16) found little or no change in serum calcium as a result of tourniquet shock in dogs, whereas we found an average increase of 34 per cent. The method of producing shock may be the explanation for the difference in results.

\section{CONCLUSIONS AND SUMMARY}

(1) In traumatic shock, the fluid which extravasates into the traumatized extremity is mobilized from the rest of the tissues of the body. A portion of it is contributed by loss of circulating plasma.

(2) The A-G ratio, as determined chemically, is higher in the leg fluid from the traumatized area than that of the plasma, in every case. Cell proteins apparently are liberated in the traumatized extremity, probably from ruptured muscle fibers.

(3) The non-protein nitrogen content of the fluid in the traumatized area is higher than that of the blood. The liberated cell proteins probably undergo breakdown into simpler nitrogenous products. The elevated blood NPN during traumatic shock may to some extent be due to absorption of these products.

(4) Alterations in electrolyte concentration of serum and tissues which occur during traumatic shock have been tabulated.

We greatly appreciate and acknowledge the collaboration of the technical group who helped make this work possible: George Casarett, John Thomas, Marion Wesley, Betty Mulryan, Marlene Falkenheim, Jerry Biondi, Edward Mulligan, and Elizabeth Vittum.

\section{BIBLIOGRAPHY}

1. Moon, V. H., Shock and Related Capillary Phenomena. Oxford University Press, New York, 1938.

2. Dunphy, J. E., Gibson, J. G. II, and Keeley, J. L., Observations on the pathology of experimental traumatic shock. Surg., Gynec. and Obst., 1941, 72, 823.
3. Blalock, A., Principles of Surgical Care: Shock and Other Problems. C. V. Mosby Co., St. Louis, 1940.

4. Ashworth, C. T., and Kregel, L. A., Changes in the body water partition and extracellular electrolytes in shock. Arch. Surg., 1942, 44, 829.

5. Ricca, R. A., Fink, K., Katzin, L. I., and Warren, S. L., Effect of environmental temperature on experimental traumatic shock in dogs. J. Clin. Invest., 1945, 24, 127.

6. Howe, P. E., The determination of proteins in blood: A micro method. J. Biol. Chem., 1921, 49, 109.

7. Koch, F. C., and McMeekin, T. H., A new direct nesslerization micro-Kjeldahl method and a modification of the Nessler-Folin reagent for ammonia. J. Am. Chem. Soc., 1924, 46, 2066.

8. Steadman, L. T., A spectrochemical determination of sodium in blood serum. J. Biol. Chem., 1941, 138, 603.

9. Steadman, L. T., The carbon arc in oxygen for the spectrochemical determination of potassium. Physical Review, 1943, 63, 322, and 1943, 63, 399.

10. Harris, P. N., and Blalock, A., Experimental shock: $\mathrm{X}$. Observations on the water content of the tissues of the body after trauma and after hemorrhage. Arch. Surg., 1931, 22, 638.

11. Ebert, P. V., Stead, E. A., Jr., Warren, J. V., and Watts, W. E., Plasma protein replacement after hemorrhage in dogs with and without shock. Am. J. Physiol., 1942, 136, 299.

12. Moon, V. H., Shock: Its Dynamics, Occurrence and Management. Lea and Febiger, Philadelphia, 1942.

13. Blalock, A., and Duncan, G. W., Traumatic shock-a consideration of several types of injuries. Surg., Gynec. and Obst., 1942, 75, 401.

14. Clarke, A. P. W., and Cleghorn, R. A., Chemical study of tissue changes in adrenal insufficiency and traumatic shock. Endocrinology, 1942, 31, 597.

15. Manery, J. F., and Solandt, D. Y., Studies in experimental traumatic shock with particular reference to plasma potassium changes. Am. J. Physiol., 1943, 138, 499.

16. Mylon, E., Winternitz, M. C., and de Süto-Nagy, G. J., Changes in serum phosphate and calcium and their relation to manifestations of traumatic shock. Am. J. Physiol., 1943, 139, 299.

17. Zwemer, R. L., and Scudder, J., Potassium changes in experimental shock. Am. J. Physiol., 1937, 119, 427. 